\title{
Peningkatan Kemampuan Menyimak Dasar Melalui Metode Mendongeng Interaktif Komunikatif
}

\author{
Acep Saepul Rahmat ${ }^{1}$, Dika Zuchdan Sumira ${ }^{2}$ \\ 1 Dinas Pendidikan Prov DKI Jakarta \\ ${ }^{2}$ Dosen Sekolah Tinggi Agama Islam Putra Galuh Ciamis \\ *email: acepsaepulrahmat.s3@student.upi.edu
}

\begin{abstract}
Improvement of Children Basic Learning Skills Through Communicative Interactive Storytelling Methods. This study aims to improve listening skills through an integrated interactive storytelling method in students of group B PAUD Al-Muqorrobin, Cigalontang District, Tasikmalaya Regency. This research is a classroom action research using the Kemmis and McTaggart models. Data was collected through observations on observations of behavior, as well as oral tests in the form of questioning and documentation. Data were analyzed through quantitative descriptive (percentages and averages). Based on data analysis, it was found that teacher and student activities increased each cycle. The average ability to listen to children in each indicator increased by 46.66\%. The average for the lowest score increased by $56.66 \%$ and for the highest score an increase of $43.33 \%$. In addition, $90 \%$ are said to meet the achievement and exceed the target and declared complete. Therefore the integrated interactive storytelling method affects the ability to listen to class B children (ages 5-6 years) in Almuqorrobin Tasikmalaya PAUD.
\end{abstract}

Keywords: method,iIntegrated interactive, storytelling, listening ability

\begin{abstract}
Abstrak. Peningkatan Kemampuan Menyimak Dasar Melalui Metode Mendongeng Interaktif Komunikatif. Penelitian ini bertujuan untuk meningkatkan kemampuan menyimak melalui metode mendongeng interaktif terpadu pada siswa kelompok B PAUD Al-Muqorrobin Kecamatan Cigalontang Kabupaten Tasikmalaya. Penelitian ini merupakan penelitian tindakan kelas dengan menggunakan model Kemmis dan McTaggart. Data dikumpulkan melalui lembar observasi pengamatan perilaku, serta tes lisan berupa pertanyaan menggali dan dokumentasi. Data dianalisis melalui deskriptif kuantitatif (presentase dan rata-rata). Berdasarkan analisis data diperoleh bahwa aktivitas guru dan siswa meningkat setiap siklus. Rata-rata kemampuan menyimak anak pada setiap indikator mengalami peningkatan sebesar 46.66\%. Rata-rata untuk skor terendah mengalami peningkatan sebesar $56.66 \%$ dan untuk skor tertinggi mengalami peningkatan sebesar $43.33 \%$. Selain itu $90 \%$ dikatakan memenuhi ketercapaian dan melebihi target serta dinyatakan tuntas. Oleh sebab itu metode mendongeng interaktif terpadu berpengaruh terhadap peningkatan kemampuan menyimak anak kelas B (usia 5-6 tahun) di PAUD Almuqorrobin Tasikmalaya.
\end{abstract}

Kata Kunci: metode interaktif terpadu, mendongeng, kemampuan menyimak 


\section{PENDAHULUAN}

Taman Kanak-kanak (TK) merupakan penyelenggaraan PAUD pada jalur pendidikan formal yang menggunakan program pembelajaran untuk anak usia dini dan memiliki peran yang sangat penting serta strategis dalam proses peletakan dasar pendidikan generasi bangsa pada masa mendatang. Taman Kanak-Kanak merupakan tahap awal proses pendidikan yang diselenggarakan secara terstruktur dalam upaya pembentukan sumber daya manusia Indonesia agar kelak mampu menjadi generasi yang handal dan mampu membangun bangsanya serta memiliki harkat dan martabat yang mampu bersaing dengan bangsa-bangsa lain di era globalisasi.

Guru sebagai pemegang kunci keberhasilan pengajaran perlu memperhatikan beberapa aspek maupun faktor perkembangan siswa. Salah satunya berkaitan dengan karaktertistik, baik karakteristik kognitif maupun afektif. Kesadaran tentang karakteristik dan faktor-faktor yang ada dalam diri siswa, hendaknya dijadikan titik tolak bagi guru untuk menciptakan kegiatan pembelajaran melalui pemilihan teknik pembelajaran yang tepat, sehingga membuat proses belajar yang efektif (Saputro, 2006).

Karakteristik kognitif yang tidak dapat lepas dalam perkembangan siswa adalah kemampuan bahasa. Perkembangan bahasa anak perlu dioptimalkan melalui stimulasi atau rangsangan, salah satunya melalui kegiatan menyimak.

Morrow (Jamaris, 2010) menjelaskan bahwa pemerolehan bahasa pada anak terjadi melalui kegiatan yang dilakukannya, mendengar bahasa dan meniru bunyi bahasa. Melalui kegiatan ini anak menemukan bahwa bahasa lisan mempunyai aturan, khususnya yang berkaitan dengan phonology atau bunyi, sintak atau tata bahasa dan semantik atau arti kata, selanjutnya secara perlahan anak akan menyadari bahwa bahasa mempunyai sistim yang perlu diikuti dengan benar agar ide dan konsep yang disampaikan dapat dimengerti oleh yang lain (Jamaris, 2010).

Oleh karena itu untuk memperoleh bahasa yang baik dan benar, anak harus memiliki kemampuan dalam mendengarkan dan menyimak. Menyimak merupakan salah satu keterampilan berbahasa yang sangat berperan dalam kehidupan manusia, lebih-lebih untuk menumbuh kembangkan kemampuan berbahasa pada anak. Selain itu kegiatan menyimak sangat berpengaruh terhadap perkembangan kognitif anak, karena dengan kegiatan menyimak, anak belajar untuk mendapatkan pengetahuan baru dan memberi ruang baru untuk berinteraksi sosial dengan lingkungannya.

Kenyataan yang terjadi bahwa kemampuan menyimak anak sangat rendah yang ditandai dengan anak kurang perhatian, anak kurang memahami serta anak kurang berapresiasi terhadap bahan materi menyimak. Kenyataan itu terjadi pada anak kelompok B PAUD AlMuqorrobin Tasikmalaya Tahun Ajaran 2018/2019 .

Berdasarkan hasil diskusi dan analisis data pengamatan dengan guru di PAUD Al-Muqorrobin Tasikmalaya, diketahui hasil kemampuan menyimak anak adalah 32,8 \%, belum sesuai dengan target atau kriteria kemampuan menyimak anak. Sejalan dengan pelaksanaan Kurikulum Tingkat Satuan Pendidikan (KTSP), salah satu upaya yang dilaksanakan di sekolah ini adalah penggunaan dongeng sebagai metode pembelajaran. Hal ini harus dilakukan 
agar kebutuhan peserta didik dapat terlayani dengan baik sesuai dengan Kurikulum Tingkat Satuan Pendidikan (KTSP).

Adapun metode-metode yang
dapat
mengembangkan kemampuan menyimak anak diantaranya adalah simak ulang ucap, simak kerjakan, simak terka, menjawab pertanyaan, paraphrase dan merangkum (Rahmat, 2017). Guru menyiapkan bahan menyimak berupa cerita atau dongeng yang tidak terlalu panjang, isi dan bahasanya juga disesuaikan dengan kemampuan anak. Setelah guru menceritakan atau mendongeng, anak ditugaskan untuk menceritakan isi cerita atau dongeng tersebut dengan bahasa atau kalimat sendiri dan dibantu oleh pertanyaan-pertanyaan guru. Metodemetode di atas cocok untuk diterapkan pada pembelajaran di Taman Kanakkanak, karena dapat meningkatkan kemampuan menyimak, selain itu mampu merangsang penguasaan kosa kata anak dan dapat mendorong anak untuk mampu melaksanakan tugas dengan baik.

Metode mendongeng merupakan salah satu metode yang dapat membantu anak dalam mengekpersikan bahasanya (Izzah \& Mutiarani, 2019). Yudha (2007) juga menjelaskan bahwa, mendongeng merupakan salah satu cara yang efektif untuk mengembangkan aspek-aspek kognitif, afektif, sosial dan aspek konatif (penghayatan). Mendongeng berarti dapat meningkatkan kemampuan berpikir anak, mengembangkan pemahaman dan memberi gambaran terhadap cara hidup bersama, Selain itu mendongeng pun dapat membawa anak-anak pada pengalaman baru yang belum pernah dialaminya.

Menyajikan sebuah dongeng pada anak TK/ PAUD dengan menggunakan berbagai media yang menarik bagi anak untuk mendengarkan dan memperhatikan ceritanya. Alat atau media yang digunakan hendaknya aman, menarik, dapat dimainkan oleh guru maupun anak dan sesuai dengan tahap perkembangan anak. Hal ini dinamakan sebagai teknik mendongeng secara interaktif terpadu (Hamdayana,2014).

Beberapa penelitian yang relevan dengan penelitian ini adalah penelitian yang dilakukan oleh Wright (2013) yang membahas tentang prosedur dan pertimbangan untuk meningkatkan kemampuan bercerita anak usia dini dan dengan mendongeng mampu menghubungkan hubungan sekolah dan rumah. Penelitian yang sama dilakukan oleh Rahayu (2000) yang menyimpulkan dengan menggunakan sandiwara boneka sebagai media pembelajaran dapat meningkatkan kemampuan dasar, pembentukan perilaku sekaligus dapat melatih daya tangkap, melatih konsentrasi, kecakapan bahasa, dan pembentukan perilaku.

Penelitian serupa juga dilakukan oleh Rejeki (2009), sebuah penelitian tindakan di SD Terpadu Insan Mandiri Kelas II Jakarta. Penelitian ini bertujan untuk meningkatkan kemampuan menyimak siswa dalam bahasa Indonesia dengan kesimpulan bahwa penggunaan metode bercerita dapat meningkatkan kemampuan menyimak siswa.

Berdasarkan analisa peneliti terhadap ketiga penelitian tersebut, metode mendongeng merupakan suatu cara yang sangat efektif untuk meningkatkan kemampuan menyimak anak. Anak usia dini berada dalam masa keemasan (golden age) disepanjang rentang usia perkembangan manusia yaitu usia 0-8 tahun. Usia keemasan merupakan masa di mana anak mulai peka untuk menerima berbagai 
stimulasi dan berbagai upaya pendidikan baik disengaja maupun tidak disengaja dan pada masa ini pula kemampuan otak anak menyerap informasi sangat tinggi. Untuk meningkatkan kemampuan menyimak pada anak usia dini, tentu diperlukan suatu strategi dalam pembelajaran yang harus dimiliki oleh pendidik salah satunya dengan menggunakan metode mendongeng.

Pemberian metode mendongeng pada anak usia dini diharapkan dapat meningkatkan kemampuan menyimak. Berdasarkan pertimbangan tersebut, maka penelitian ini mencoba untuk melakukan tindakan evaluatif dan melakukan peningkatan kemampuan menyimak melalui metode mendongeng interaktif terpadu.

\section{METODE}

Penelitian ini menggunakan metode penelitian tindakan (action research) dengan batasan kelas atau classroom action research (penelitian tindakan kelas) dengan menggunakan model Kemmis dan Mc Taggart. Penelitian tindakan ini dilakukan dalam dua siklus. Setiap siklus terdiri dari tahapan perencanaan, tindakan, observasi dan refleksi. Metode penelitian action research ini dilaksanakan untuk meningkatkan kemampuan menyimak siswa kelompok B PAUD AlMuqorrobin Kecamatan Cigalontang Kabupaten Tasikmalaya Tahun ajaran 2018/2019.

Adapun populasi dalam penelitian ini PAUD Al-Muqorrobin Kecamatan Cigalontang Kabupaten Tasikmalaya berjumlah 20 orang yakni 10 orang lakilaki dan 10 orang perempuan. Instrumen penelitian terdiri lembar observasi pengamatan perilaku, tes lisan mengenai isi cerita dongeng dan dokumentasi. Analisis data penelitian dilakukan melalui deskriptif kuantitatif, rat-rata (mean) dan presentase.

\section{HASIL DAN PEMBAHASAN}

\section{HASIL}

Hasil penelitian ini berhubungan dengan peningkatan kemampuan menyimak siswa melalui metode mendongeng interaktif terpadu pada kelompok B PAUD Al-Muqorrobin Kecamatan Cigalontang Kabupaten Tasikmalaya Tahun ajaran 2018/2019. Diadakannya penelitian ini, bertujuan untuk melihat peningkatan kemampuan menyimak isi cerita berdasarkan indikator menyimak serta hasil observasi pengamatan perilaku siswa selama proses pembelajaran melalui metode mendongeng interaktif terpadu pada kelompok B PAUD AlMuqorrobin Kecamatan Cigalontang Kabupaten Tasikmalaya Tahun ajaran 2018/2019.

Hasil analisis data diperoleh bahwa aktivitas guru dan siswa meningkat setiap siklus. Rata-rata kemampuan menyimak pada pra tindakan dengan persentase $27 \%$ dari total indikator kemampuan menyimak. Pada siklus I persentase $43 \%$ dari total indikator kemampuan menyimak dan siklus II mengalami peningkatan yang sangat signifikan yakni sebesar $90 \%$ dari pencapaian indikator kemampuan menyimak.

Untuk melihat secara jelas mengenai peningkatan tes hasil belajar dan skor keterampilan sosial siswa pada proses pembelajaran Ilmu Pengetahuan Sosial materi sumber daya alam dan pemanfaatannya disajikan dalam analisis data berikut. 
Tabel 1. Analisis Data Kemampuan Menyimak Siswa Kelompok B pada Pra tindakan, Siklus I dan Siklus II

\begin{tabular}{|c|c|c|c|c|c|c|}
\hline \multirow[t]{2}{*}{ NO } & \multirow{2}{*}{$\begin{array}{c}\text { Aspek } \\
\text { Pembanding }\end{array}$} & \multirow{2}{*}{$\begin{array}{c}\text { Pra } \\
\text { Tindakan }\end{array}$} & \multirow{2}{*}{$\begin{array}{c}\text { Siklus } \\
\text { I }\end{array}$} & \multirow{2}{*}{$\begin{array}{c}\text { Siklus } \\
\text { II }\end{array}$} & \multicolumn{2}{|c|}{ Peningkatan } \\
\hline & & & & & $\begin{array}{l}\text { Nilai/ } \\
\text { Skor }\end{array}$ & $\%$ \\
\hline 1. & $\begin{array}{l}\text { Skor Rata- } \\
\text { rata } \\
\text { indikator }\end{array}$ & 13 & 16 & 27 & 14 & 46,66 \\
\hline 2. & $\begin{array}{l}\text { Skor } \\
\text { terendah }\end{array}$ & 5 & 13 & 22 & 17 & 56,66 \\
\hline 3. & $\begin{array}{l}\text { Skor } \\
\text { tertinggi }\end{array}$ & 16 & 18 & 29 & 13 & 43,33 \\
\hline 4. & Tuntas & 2 & 9 & 18 & 14 & 90 \\
\hline
\end{tabular}

Berdasar tabel 1 tentang analisis data kemampuan menyimak siswa kelompok B PAUD Al-Muqorrobin pada pra tindakan, siklus I dan siklus II siswa mulai dari pra tindakan, siklus I dan siklus II, maka didapatkan data bahwa pada pra tindakan ketercapaian indikator kemampuan menyimak sebesar 13, pada siklus I 16 dan pada siklus II mengalami peningkatan yang signifikan yakni rata-rata ketercapaian indikator kemampuan menyimak adalah 27 dari 30 item indikator kemampuan menyimak. Hal ini membuktikan adanya peningkatan yang cukup besar yakni berkisar $70 \%$ meningkat dari ketercapaian indikator sebanyak 2 orang atau $10 \%$ menjadi 18 orang atau $90 \%$ dari total siswa kelompok B PAUD AlMuqorrobin Tasikmalaya. Untuk aspek skor ketercapian indikator kemampuan menyimak terendah adalah 5 pada pra tindakan, siklus I 13 dan siklus II mengalami peningkatan yakni 22 . Untuk aspek skor ketercapian indikator kemampuan menyimak tertinggi pada saat pra tindakan sebesar 16, siklus I 18 dan siklus II 29. hal ini menunjukkan adanya peningkatan yang cukup besar yakni $90 \%$ dikatakan memenuhi ketercapaian dan melebihi target dan dinyatakan tuntas.

Untuk memperjelas peningkatan aspek nilai rata-rata kelas, nilai tertinggi dan nilai ter rendah, maka masingmasing aspek maka digambarkan dalam bentuk grafik 1 dan grafik II berikut.

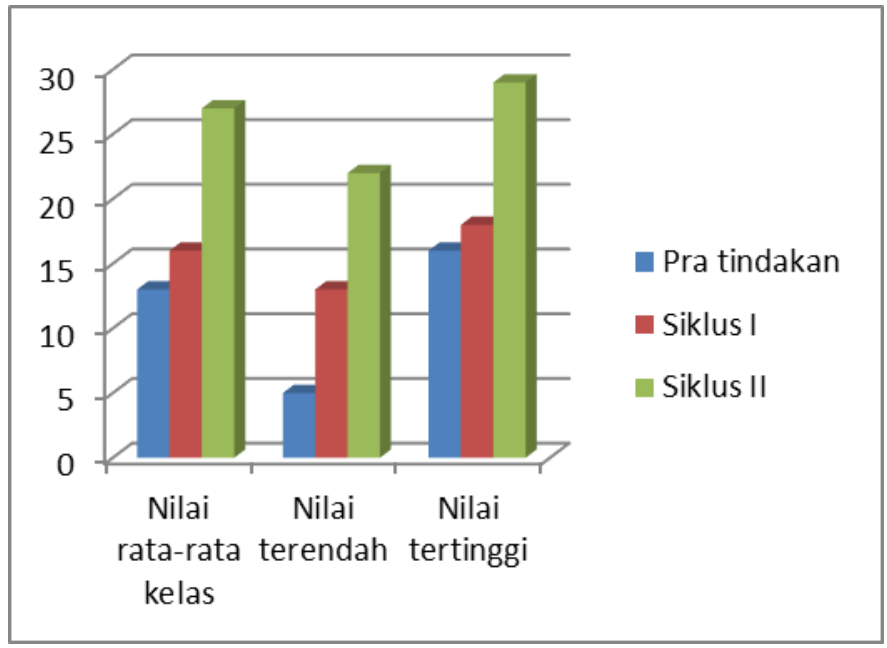

Gambar 1. Analisis Data Kemampuan Menyimak Siswa pada Pra tindakan, Siklus I dan Siklus II

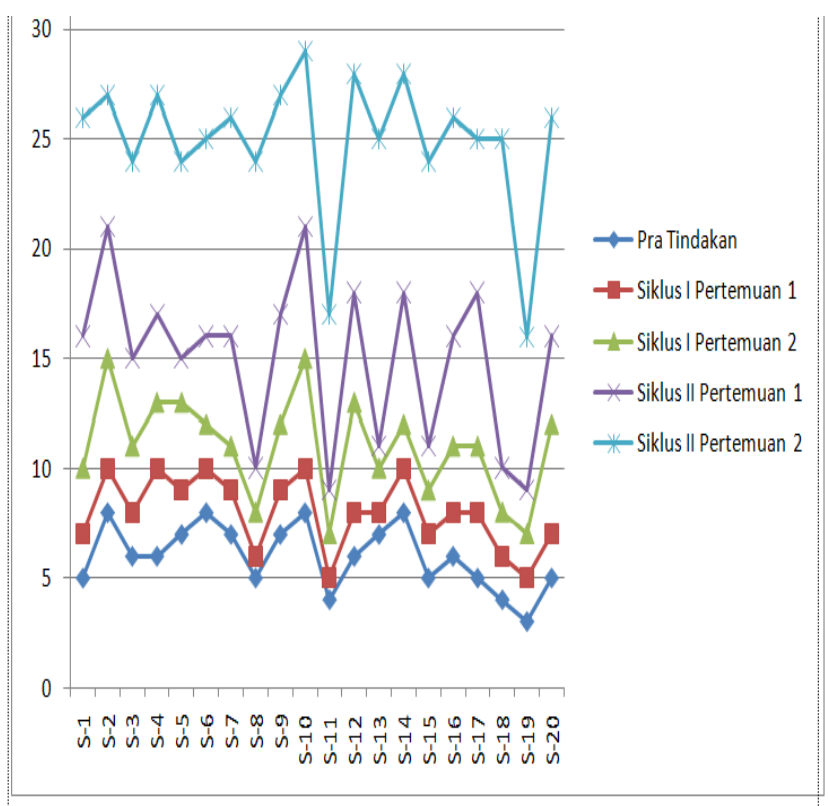

Gambar 2. Diagram Garis Analisis Data Kemampuan Menyimak Siswa pada Pra tindakan, Siklus I dan Siklus II

Berdasarkan gambar (1) dan gambar (II) terlihat jelas bahwasanya peningkatan kemampuan menyimak siswa kelompok B PAUD AlMuqorrobin pada pra tindakan, siklus I dan siklus II melalui metode mendongeng interaktif terpadu menunjukkan peningkatan yang sangat 
signifikan dan melampaui kriteria ketuntasan minimal yang ditetapkan. Berdasarkan data tersebut dinyatakan bahwa kemampuan menyimak siswa kelompok B PAUD Al-Muqorrobin kecamatan cigalontang tasikmalaya melalui metode mendongeng interaktif terpadu dinyatakan tuntas pada siklus II pertemuan kedua.

\section{PEMBAHASAN}

Pembangunan pendidikan nasional didasarkan pada paradigma membangun manusia Indonesia seutuhnya untuk mengaktualisasikan potensi dan dimensi kemanusiaan secara optimal, baik dimensi afektif, kognitif maupun psikomotor. Pendidikan merupakan usaha sadar dan terencana untuk mewujudkan suasana belajar dan proses pembelajaran agar peserta didik secara aktif mengembangkan potensi dirinya untuk memiliki kekuatan spiritual keagamaan, pengendalian diri, kepribadian, kecerdasan, akhlak mulia, serta keterampilan yang diperlukan dirinya, masyarakat, bangsa, dan negara.

Pemerintah dalam hal ini telah mengatur dan mengarahkan pendidikan nasional seperti yang tertuang dalam Undang-Undang Nomor 20 tahun 2003 tentang Sistem Pendidikan Nasional. Bahwa tujuan dari pendidikan nasional adalah mencerdaskan kehidupan bangsa dan mengembangkan manusia Indonesia seutuhnya, yaitu manusia yang beriman dan bertakwa kepada Tuhan Yang Maha Esa dan berbudi pekerti luhur, memiliki pengetahuan dan keterampilan, kesehatan jasmani dan rohani, kepribadian yang mantap dan mandiri serta mempunyai tanggung jawab kemasyarakatan dan kebangsaan. (Asmawati, 2008).

Pembangunan nasional yang sedang dilaksanakan bertujuan untuk membangun manusia Indonesia seutuhnya. Berhasil tidaknya program pembangunan faktor manusia memegang peranan yang sangat penting. Untuk pembangunan itu diperlukan manusia yang berjiwa pemikir, kreatif dan mau bekerja keras, serta memiliki pengetahuan dan keterampilan, memiliki sifat positif terhadap etos kerja.

Undang-undang RI Nomor 20 Tahun 2003 tentang Sistem Pendidikan Nasional pasal 1, angka 14 menyatakan bahwa Pendidikan Anak Usia Dini (PAUD) adalah suatu upaya pembinaan yang ditujukan kepada anak sejak lahir sampai dengan usia enam tahun yang dilakukan dengan pemberian rangsangan pendidikan untuk membantu pertumbuhan dan perkembangan jasmani dan rohani agar anak memiliki kesiapan dalam memasuki pendidikan lebih lanjut (Kemendiknas, 2010).

Para ahli pendidikan memandang bahwa usia prasekolah merupakan masa emas bagi penyiapan anak untuk menjalani proses perkembangan dan belajar selanjutnya. Pada usia ini pula terdapat "masa peka" yang sangat potensial sekali untuk dikembangkan secara optimal sebagai tuntutan perkembangan anak.

Untuk memenuhi kebutuhan anak pada masa keemasan, orang tua atau guru harus memahami sifat khusus yang dimiliki anak-anak, yakni :

1. Banyak bergerak, gemar bermain dan bersuka ria;

2. Selalu ingin meniru;

3. Memiliki daya ingat yang sangat kuat;

4. Senang dimotivasi (dipuji);

5. Cepat menguasai bahasa. (Kusmayadi, 2011:9).

Keterampilan berbahasa (language arts, language skills) 
mencakup empat komponen, yaitu keterampilan menyimak/mendengar (listening skills), keterampilan berbicara (speaking skills), keterampilan membaca (reading skills), dan keterampilan menulis (writing skills) (Tarigan, 2008).

Keterampilan menyimak merupakan salah satu aspek keterampilan berbahasa yang peranannya sangat penting dalam kehidupan manusia. Secara alamiah setiap anak yang normal belajar bahasa melalui proses mendengarkan atau menyimak. Melalui proses tersebut akhirnya anak dapat belajar berbicara. Pengembangan kemampuan berbahasa lisan terkait pada lingkungan dimana anak tinggal, lingkungan yang banyak memberikan stimulasi akan memperkaya berbendaharaan kata anak.

Oleh karena itu diharapkan baik orang tua dan guru agar dapat memberikan stimulasi pada anak agar kemampuan bahasa lisannya dapat berkembang secara optimal (Dhieni, 2011). Kemampuan menyimak sebagai salah satu kemampuan berbahasa awal yang harus dikembangkan, memerlukan bahasa reseptif dan pengalaman, dimana anak sebagai penyimak secara aktif memproses dan memahami apa yang didengar.

Beberapa pakar bahasa mendefinisikan kemampuan menyimak sebagai kemampuan memusatkan perhatian, kemampuan mengingat, kemampuan menangkap bunyi, kemampuan linguistik, kemampuan non-linguistik, kemampuan menilai, serta kemampuan menanggapi (Tarigan, 2008). Setiap orang yang yang terlibat dalam proses menyimak memerlukan sejumlah kemampuan untuk dapat menguasai bahasa, menambah wawasan, dan mendapatkan informasi.

Bromley (1992) menyatakan bahwa, kemampuan menyimak adalah :
Effective listening occurs when a listener uses auditory, acuity and discrimination to identify sounds and words and the translate these words into meaning by auding or komprehending. Listening comprehension cannot be said to occur when speaker's message is morely docoded, in order for comprehension to occur must be an active participan in the transaction as he hears, identifies, and associates meaning with the sound of languange.

Hal ini menggambarkan bahwa proses menyimak aktif terjadi ketika anak sebagai penyimak menggunakan auditory discrimination dan acuity dalam mengidentifikasikan suara-suara dan berbagai kata, kemudian menterjemahkannya menjadi kata yang bermakna melalui pemahaman (Freeman, 2015). Penyimak aktif bukan sekedar menterjemahkan pesan pembicara, namun terlibat sebagai peserta aktif dengan mendengarkan, mengidentifikasi, dan mengasosiasikan arti dengan suara bahasa yang disampaikan. Sebagaimana juga dijelaskan oleh Bromley (1992) bahwa kemampuan menyimak adalah kemampuan bahasa respetif yang melibatkan beberapa faktor yaitu acuity, auditory discrimination, dan auding.

Dhieni (2011) menguraikan bahwa, kemampuan menyimak adalah kemampuan yang melibatkan proses menginterpretasi dan menerjemahkan suara yang didengar sehingga memiliki arti yang tertentu serta melibatkan proses kognitif yang memerlukan perhatian dan konsentrasi dalam rangka memahami arti informasi yang disampaikan.

Berkembangnya kemampuan 
menyimak pada anak dikarenakan adanya kemauan untuk memperhatikan dan mendengarkan segala bentuk informasi yang disampaikan sehingga mampu memaknainya sebagai satu pengetahuan baru.

Pendapat di atas dipertegas oleh Herrick dan Jacob (1988), bahwa :

"Listening is only facet of comunikation, the speaker translates a thought or idea into speech symbol for the purposetive one. He takes word symbol and interprets them in the liight of his awn previos expriense. He translate the oral symbol into known or rearrangement of the old".

Hal di atas menerangkan bahwa menyimak adalah salah satu segi dalam komunikasi.

Pembicara menterjemahkan pikiran atau ide melalui simbol-simbol lisan untuk tujuan komunikasi dengan lawan bicara. Aturan pendengar adalah menginterpretasikan apa yang didengar untuk memperoleh informasi. Pendengar mengambil simbol-simbol kata dan menginterpretasikan simbol oral melalui konsep pengetahuan atau meninjau kembali konsep itu dengan menambah elemen baru atau menyusun kembali yang lama.

Kemampuan menyimak mencakup dalam tiga kawasan (domain) perilaku yaitu kawasan afektif, kawasan kognitif, dan kawasan psikomotor. Kawasan afektif berisi hal-hal yang berkenaan dengan minat dan bakat, kawasan kognitif mengenai aspek intelektual atau fungsi pikir, dan kawasan psikomotor mengenai aspek keterampilan motorik (Azwar, 1987). Apabila ketiga kawasan itu mampu dikembangkan oleh pendidik dalam merangsang kemampuan menyimak anak maka pembelajaran yang dirancang berhasil.

Bromley (1992) menjelaskan ada tiga faktor yang mempengaruhi terhadap kemampuan menyimak anak yaitu :

1. Faktor penyimak, terdiri dari tujuan, tingkat pemahaman konseptual, pengalaman, dan strategi monitoring dalam proses pemahaman.

2. Faktor situasi, terdiri dari lingkungan dan fisik.

3. Faktor pembicara, terdiri dari redundancy, pengupacapan kata, dan kontak mata.

Berdasarkan

faktor-faktor tersebut, kondisi fisik dan tingkat pemahaman anak merupakan faktor penting dalam menentukan keefektifan dan kualitas keaktifan menyimak. Faktor situasi yang terdiri dari kondisi lingkungan fisik dan sosial juga dapat memotivasi kegiatan menyimak, serta pengucapan kata yang jelas dari pembicara turut mempengaruhi kegiatan menyimak anak (Tarigan, 2008). Menyimak itu sendiri memiliki empat tahapan yaitu (1) Hearing, (2) understanding, (3) evaluating, responding (Walter, 1975).

Pengembangan kemampuan menyimak tentunya perlu diadaptasi dalam proses pembelajaran, agar hasilnya optimal. Esensi pembelajaran mengacu pada empat komponen yaitu peserta didik, tujuan pembelajaran, metode pembelajaran, dan penilaian proses pembelajaran. Metode terkait dengan strategi pembelajaran yang sebaiknya dirancang agar proses belajar berjalan dengan maksimal.

Metde adalah cara-cara yang berbeda untuk mencapai hasil yang berbeda di bawah kondisi yang berbeda (Degeng, 2005). Pada dasarnya semua cara ini dapat dimanipulasi oleh seorang 
pendidik sedemikian rupa dengan memperhatikan karakteristik dan kemampuan anak melalui kegiatan yang menarik.

Salah satu kegiatan pembelajaran yang dapat meningkatkan kemampuan menyimak atau bahasa adalah melalui kegiatan mendongeng. Hal ini dijelaskan dalam beberapa hasil penelitian yang menyatakan bahwa mendongeng dapat meningkatkan kemampuan berbasaha ekspresif anak usia dini (Izzah et al., 2019). Selain itu mendongeng juga dapat memberikan stimulasi yang mendorong karakter positif serta pengembangan bahasa (Green, 2015).

Behjat (2012) menjelaskan bahwa mendongeng adalah menceritakan atau mengajarkan anakanak mengenai perilaku moral, keyakinan dan dapat menciptakan situasi yang menyenangkan bagi anak. Dengan mendongeng bisa menanamkan nilai-nilai kehidupan sejak dini dalam suatu pembelajaran yang menarik, sehingga anak tidak merasa digurui.

Mendongeng juga adalah bercerita atau menceritakan dongeng (Zeece, 1977). Apabila disimak, ditelaah, dan juga ditelusuri lebih jauh atau lebih mendalam dari pengertian bercerita atau mendongeng, ternyata kita bisa menemukan adanya cerita atau dongeng, pencerita dan pendengar.

Pada dasarnya bercerita itu melibatkan tiga hal yaitu: 1) adanya bahan cerita/dongeng, 2) adanya orang yang akan bercerita, 3) adanya orang yang bakal mendengarkan cerita/dongeng dari orang yang akan bercerita/mendongeng.

Dari beberapa pendapat di atas dapat disimpulkan bahwa mendongeng adalah kegiatan menceritakan dongeng, yaitu cerita tentang kejadian masa lampau yang tidak benar-benar terjadi, baik yang tertulis maupun tidak tertulis yang diceritakan secara turun-temurun dalam situasi yang menyenangkan bagi anak.

Jadi metode mendongeng adalah cara atau teknik yang berbeda yang dilakukan oleh guru dalam kegiatan menceritakan dongeng, yaitu cerita tentang kejadian masa lampau yang tidak benar-benar terjadi, dalam situasi yang menyenangkan bagi anak agar tujuan dapat tercapai secara efektif dan efisien.

Tujuan mendongeng dengan alat peraga agar anak dapat menanggapi secara tepat terhadap isi dongeng yang sedang disampaikan guru. Dengan alat peraga sebagai pendukung cerita dan alat interaktif terpadu membantu imajinasi anak untuk memahami isi cerita.

Anak usia dini adalah anak yang baru dilahirkan sampai usia 6 tahun. Usia ini merupakan usia yang sangat menentukan dalam pembentukan karakter dan kepribadian anak (Sujiono, 2009). Anak usia dini merupakan kelompok anak yang berada dalam proses pertumbuhan dan perkembangan yang bersifat unik, artinya memiliki pola pertumbuhan dan berkembangan fisik (koordinasi motorik kasar dan halus), kecerdasan (daya pikir, daya cipta), sosio emosional, bahasa dan komunikasi.

Seefeldt dan Barbour (1983) menglasifikasikan pembagian rentang usia berdasarkan keunikan dalam tingkat pertumbuhan dan perkembangan anak usia dini yaitu: tahap infancy usia 0 sampai 1 tahun, tahap toddler yaitu usia 1 sampai 3 tahun, tahap pre-school yaitu usia 3 sampai 4 tahun, tahap early primary years yaitu usia 5 sampai 6 tahun, dan tahap later primary years yaitu usia 7 sampai 8 tahun. Anak usia dini berada dalam masa keemasan disepanjang rentang usia perkembangan manusia. 
Beberapa pakar berpendapat berbeda dalam menentukan rentang waktu usia golden age. Ada yang menyatakan 0-2 tahun, ada juga yang menyatakan 0-8 tahun. Meskipun ada perbedaan pendapat tetapi semua sepakat bahwa awal-awal tahun pertama kehidupan anak adalah masa-masa emas mereka.( Kusmayadi, 2011)

Yuliani (2010) menyatakan bahwa usia keemasan merupakan masa di mana anak mulai peka untuk menerima berbagai stumulasi dan berbagai upaya pendidikan dari lingkungan baik disengaja maupun tidak disengaja. Pada masa peka inilah terjadi pematangan fungsi-fungsi fisik dan psikis sehingga anak siap merespon tugas-tugas perkembangan yang diharapkan muncul pada pola perilaku sehari-hari.

Menurut the National Assosiation for the Education of Young Children (NAEYC), yang disebut masa anak usia dini adalah periode sejak kelahiran hingga usia delapan tahun. "early childhood refers to the child from birth to age eight" (George, 1988:4).

Dari beberapa pendapat di atas, dapat disimpulkan bahwa anak usia dini adalah anak yang sejak kelahiran sampai dengan usia delapan tahun, yang berada dalam masa pertumbuhan dan perkembangan dan merupakan masa peka untuk menerima berbagai stimulasi dan upaya pendidikan.

Kemampuan menyimak merupakan kemampuan menangkap atau mendengarkan bunyi, baik bunyi non bahasa maupun bunyi bahasa dengan penuh pemahaman, perhatian, apresiasi, serta interprestasi, dengan menggunakan aktivitas telinga dalam menangkap pesan yang diperdengarkan untuk memperoleh informasi.

Metode mendongeng merupakan suatu cara atau teknik yang berbeda yang dianggap jitu dalam menceritakan dongeng, supaya tujuan pembelajaran dapat tercapai secara efektif dan efisien. Dongeng adalah cerita rakyat tentang kejadian masa lampau yang tidak dianggap benar-benar terjadi, yang diceritakan secara turun-temurun.

Biasanya dongeng mengisahkan tentang binatang yang seolah-olah bisa berbicara seperti manusia, asal mula terjadinya suatu tempat, tentang dunia dewa-dewa, dan lain-lain. Mendongeng memiliki potensi untuk menumbuhkan kemampuan berbahasa anak, salah satunya adalah kemampuan menyimak, memperkuat imajinasi, meningkatkan empati dan pemahaman, memperkuat nilai dan etika, serta merangsang proses pemikiran kritis dan kreatif anak.

Anak-anak sangat senang apabila diceritakan suatu dongeng, kadang ketertarikannya tidak cukup lama dikarenakan guru atau seseorang yang menceritakan dongeng kurang terampil dalam mendongeng. Untuk menarik anak dalam mendengarkannya maka guru atau pendongeng harus menguasai cara atau teknik dalam mendongeng.

\section{SIMPULAN DAN SARAN}

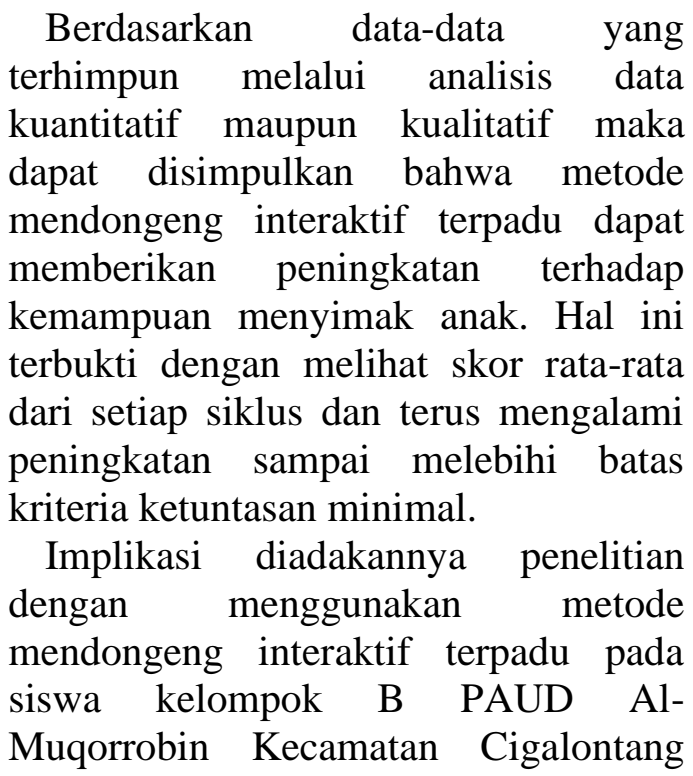


Kab. Tasikmalaya terhadap pasrtisipan yaitu, adanya pengaruh terhadap aktivitas pembelajaran menjadi aktif, interaktif dan menyenangkan. Siswa sangat antusias, tertarik bahkan sampai membuat siswa mudah memahami kontesk isi cerita yang diberikan secara cepat. Selain dari itu kemampuan senso motorik halus dan kasar menjadi terasah, serta menambah pengalaman, pemahaman, sikap dan keterampilan yang dibutuhkan pada jenjang PAUD untuk memperoleh kemampuan kognitif, senso motorik audio, visual dan audio visual yang lebih baik.

\section{REFERENSI}

Asmawati, L. (2008). Dasar-dasar Pendidikan Anak Usia Dini Secara Islami. Jakarta: Darul Qalam.

Azwar, S. (1987). Tes Prestasi, Fungsi dan pengembangan Pengukuran Prestasi Belajar, Edisi II. Yogyakarta: Bina Insani.

Behjat, F. (2012). Interpersonal and Intrapersonal Intelligences and Language Litelature: Do They Really Work InforeignLanguage Learning?. Jurnal Online: Elsevier, Procedia Social and Behavioral Sciences. Elsivier Ltd. Vol.32 (2012) P.355: 1877-0428.

Bromley, KDA. (1992). Languange Arts: Exploring Connection Second Edition. New York: Simon and Schuster.

Degeng, NS. (2005). Belajar dan Pembelajaran. Malang: Universitas Negeri Malang

Dhieni, N., et.al. (2011). Metode Pengembangan Bahasa. Jakarta: Universitas Terbuka.

Freeman, J. (2015). Developing Social Skills Literature Skill and Relationships. Reclaiming
Journal. 23(4):51.

George, S. (1988). Morrison, Early Choldhood Education Today, fourth edition. USA: Merryl Publishing Company.

Hamdayana. (2014). Model dan Metode Pembelajaran Kreatif dan Berkarakter. Bogor: Ghalia Indonesia.

Herrick, VE \& Jacob, LB. (1988). Children and Languange Arts Englewood Cliff: California: Pearson.

Jamaris, M. (2010). Orientasi Baru dalam Psikologi Pendidikan. Jakarta: Yayasan Penamas Murni.

Kusmayadi, I. (2011). Membongkar Kecerdasan Anak, Mendeteksi Bakat dan Minat Anak Jakarta: Gudang Ilmu.

Rahayu, C.P. (2000). Penggunaan Sandiwara Boneka Sebagai Media Pembelajaran. Penelitian Ilmiah. Jakarta: Teknologi Pendidikan.

Rahmat. (2017). Games Book sebagai Media Peningkatan Minat Baca pada Pembelajaran Bahasa Indonesia SD Kelas Tinggi. Jurnal IJPE UPI. 1(1):27-33.

Rejeki, S. (2009). Peningkatan Kemampuan Menyimak Melalui Metode Mendongeng. Jakarta: Pendidikan Anak Usia Dini.

Saputro, S. (2006). Strategi Pembelajaran. Malang:

Universitas Negeri Malang.

Seefeldt, C \& Barbour, N. (1983). Early Childhood Education. New York: Mc. Millan.

Sujiono, YN. (2009). Konsep Dasar Pendidikan Anak Usia Dini. Jakarta: PT. Indeks.

Tarigan, H.G. (2008). Membaca Sebagai Suatu Keterampilan Bahasa. Bandung: Angkasa. 
Walter, TP \& Julie, MJ. (1975).

Developing Children Language.

Boston: Allyn and Bacon, Inc.

Wright, C, et.al. (2013). Windows into

Children's Thinking: A Guide to Storytelling and Dramatization. Early Childhood Education Journal. 2 (7).

Yudha, A. (2007). Cara Pintar Mendongeng. Bandung: Dar Mizan.

Yuliani N.S. (2010). Bermain Kreatif Berbasis Kecerdasan Jamak. Jakarta: PT. Index.

Zeece, PD. (1977). Bringing Book to Life: $\quad$ Literatur-Based Storytelling. New York: Human Sience Press.Inc 